\title{
The Overview of Members of Student Mountaineering Club Knowledge Level of Hypothermia First Aid
}

\author{
Djoni Kusumah* \\ Department of Anesthesia, Medical Faculty \\ Universitas Jenderal Achmad Yani \\ Cimahi, Indonesia \\ *djoni.kusuma@fk.unjani.ac.id \\ Ania Kurniawati \\ Department Microbiology, Medical Faculty \\ Universitas Jenderal Achmad Yani \\ Cimahi, Indonesia
}

\author{
Alfian Ramadhan \\ Medical Faculty \\ Universitas Jenderal Achmad Yani \\ Cimahi, Indonesia
}

Danial Ahmad Dzulfikri

Medical Faculty

Universitas Jenderal Achmad Yani

Cimahi, Indonesia

\begin{abstract}
Hypothermia is a common condition in the mountain and is very dangerous problem due to an unnatural decrease in body temperature caused by long and humid exposure to cold temperatures. Lack of climbing knowledge causes climbers not to be able to perform proper assistance hence it can be risky for a climber. First aid for hypothermia is the basic and foremost skill to have for Nature Lover Students to prevent the adverse effects of hypothermia. This study aims to describe the level of knowledge about the first aid for hypothermia. This study used a descriptive method and the study subjects consisted of 57 members of Student Mountaineering Club. The data collection method used a questionnaire, then it was processed and analyzed based on percentage. The data results of 57 participants showed that 10 participants $(17.5 \%)$ had good knowledge, 26 participants $(45.6 \%)$ had moderate knowledge and 21 participants $(36.8 \%)$ had poor knowledge. The knowledge level results from the age of 20-25 years showed that 9 participants $(18 \%)$ had good knowledge. The knowledge level results based on the length of the membership who have been participated more than 3 years showed that 6 participants $(22.22 \%)$ had good knowledge. The knowledge level results based on the experience performing first aid for hypothermia in 41 participants showed that 8 participants $(19.511 \%)$ had good knowledge. From 16 participants who have not been performing first aid for hypothermia, 2 of them $(12.50 \%)$ had good knowledge. The study results showed that most of the participants have a moderate level of knowledge.
\end{abstract}

Keywords-first aid, hypothermia, level of knowledge

\section{INTRODUCTION}

Cold temperature is a low temperature when compared to normal human body temperature, so prolonged exposure to cold can cause injury due to the body's inability to adapt to cold temperatures and can be called hypothermia [1]. Hypothermia is a medical disorder that occurs in the body where a temperature drop occurs/body temperature that is not normal because the body is no longer able to produce heat to compensate and replace the body heat that is lost quickly. A person can be said to be hypothermic if his body temperature drops to $<35^{\circ} \mathrm{C}$ or lower. Hypothermia is divided into three classifications, namely mild $\left(32-35^{\circ} \mathrm{C}\right)$, moderate $\left(30-32^{\circ} \mathrm{C}\right)$, and severe $\left(<30^{\circ} \mathrm{C}\right)$ hypothermia $[2,3]$

Hypothermia is the cause of death cases during the period 1979 to 1998 as many as 700 people per year in the US. The death rate from hypothermia varies from 30 to $80 \%$, and is caused by alcohol, drugs and prolonged exposure to cold temperatures [2].

Some of the factors that can cause hypothermia, namely exposure to cold and humid environments cause a rapid decrease in body temperature and have the highest risk. A decrease in body temperature can cause changes in body physiology so that there will be disruption in the response to thermoregulation, cellular dysfunction, ischemia, and edema. This will contribute to decreased consciousness until death. Someone who experiences hypothermia can occur in those who participate in outdoor activities, such as nature-loving activities, one of which is mountains [3]

Mountain is a form of land surface that is located much higher than the surrounding lands and has a variable altitude character, so that the temperature of the mountains is lower than the surface of other soils, this will occur the most frequent risk of being hit by mountain climbers, namely hypothermia [4]. 
Student Mountaineering Club is a groups of students that doing some activities in the wild. Their activity are closely related to mountain climbing activities. Accidents or weather from a mountain are a risk factor for some people who climb, one of which is hypothermia which is caused due to inadequate knowledge of hazards or risk factors when doing mountain activities [4].

Physical conditions greatly affect the risk of hypothermia. Someone has heat energy if exposed to cold environmental temperatures for a long time will cause heat loss from the body until the body temperature is the same as the ambient temperature. In this event there will be an increased metabolic response to produce more heat so that energy consumption will be higher. This causes mountain climbers to have only a few reserves of body energy so that they experience hypothermia [5].

A person who has been exposed to cold weather should be knowledgeable about the need for adequate clothing and the importance of avoiding the use of alcohol, drugs and caffeine during exposure to cold [6].

Mountain climbers in Indonesia who experienced hypothermia in 2017 , there were 7 victims who died due to melting and hypothermia. From 2013 to 2015, 18 people died while climbing due to hypothermia. This number increased in 2016. Within 3 months, 1 person died on Mount Merbabu in February 2016 [7,8].

The importance of Student Mountaineering Club knowledge in order to avoid hypothermia, without knowledge someone can do help improperly and do not understand what to do when hypothermia starts to attack. This can happen anywhere and anytime [9].

Knowledge can be assessed using a questionnaire measuring tool which contains questions about hypothermia and hypothermia first aid which of course must have been valid and distributed to members of Mahatala Unjani, so that they can see the results of the knowledge of Mahatala Unjani members whether it is said to be good, sufficient, lacking and can be used as material. Evaluation for Mahatala Unjani members [10].

Knowledge of first aid can be influenced by various factors, namely a person's level of education, information about a subject, age, socio-culture and economy, environment and experience. Climbers who lack knowledge cause climbers to be unable to provide first aid or correct and appropriate action so that it can be risky for a climber and death will occur [11]. Based on research conducted by Joseph in India in 2014 the prevalence of first aid knowledge level is $13.8 \%$ have good knowledge, $68.4 \%$ have sufficient knowledge, and $17.8 \%$ have low knowledge [12].

Naldi et al., showed a significant relationship with a strong correlation between the level of knowledge of hypothermia and the first treatment of hypothermia in students who love nature [13].
Knowledge and first aid on hypothermia is the basic and foremost thing for Nature Lovers Students in order to prevent the bad effects of hypothermia. Because Nature Lovers Students are a group at risk of experiencing hypothermia, they are closely related to mountain climbing activities. For this reason, the authors are interested in investigating the level of knowledge of hypothermic first aid in Mahatala Unjani members.

\section{RESEARCH METHODS}

This research was conducted using purposive sampling method by considering certain criteria that must be met by respondents using primary data, with the inclusion criteria of Student Mountaineering Club in Unjani who have participated in the DIKLATSAR and who are willing to become respondents. The respondents are the students who join Mahalata group, which is a groups of students Unjani that doing some activities in the wild. Their activity are closely related to mountain climbing activities

The data obtained will then be examined with an analysis that describes the level of knowledge of hypothermic first aid for members of the Mahatala Unjani used the independent sample t test. Data analysis was performed using the Statistical Product and Service Solution (SPSS) program for Windows version 18.0 at $95 \%$ confidence level.

\section{RESULTS AND DISCUSSION}

This study was to determine the level of knowledge of hypothermic first aid among members of Mahatala Unjani by using primary data. The selection of the research sample used the total random sampling method which then obtained 57 research samples who met the inclusion criteria with a descriptive research design.

\section{A. Description of Respondent Gender Characteristics}

The description of the characteristics of the gender of the members of Mahatala Unjani can be seen in Table 1 below.

TABLE I. DESCRIPTION OF THE GENDER CHARACTERISTICS OF THE RESPONDENTS

\begin{tabular}{|c|c|c|}
\hline Characteristic & Freouency & Percentage \\
\hline Gender & Frequency & Percentage \\
\hline Men & 39 & 68.4 \\
\hline Women & 18 & 31.6 \\
\hline Total & 57 & 100.0 \\
\hline
\end{tabular}

Based on Table 1, it shows that the male respondents were 39 people $(68.4 \%)$, then 18 people were female $(31.6 \%)$.

The results above show that Mahatala Unjani members are more male than female because the male gender tends to play a type of game that emphasizes competition, physical strength, and courage, while women have the less physical strength and courage to do something that requires strong mental strength, 
so it can be seen from the results above that more men follow Mahatala Unjani [13].

\section{B. Description of Respondent Age Characteristics}

The age categories in this study were grouped into 3 groups, namely those aged $<20$ years, $20-25$ years, and $26-30$ years. The description of the characteristics of the respondents of Mahatala Unjani members based on age can be seen in Table 2 below:

TABLE II. DESCRIPTION OF RESPONDENT AGE CHARACTERISTICS

\begin{tabular}{|l|c|c|}
\hline \multicolumn{1}{|c|}{ Characteristic } & \multirow{2}{*}{ Frequency } & \multirow{2}{*}{ Percentage } \\
\hline <20 years & 5 & 8.8 \\
\hline 20-25 years & 50 & 87.7 \\
\hline 26-30 years & 2 & 3.5 \\
\hline Total & 57 & 100.0 \\
\hline
\end{tabular}

Based on Table 2, the distribution of respondents' ages obtained from the results of the study was the most in the 20-25 year age group, namely, 50 people $(87.7 \%)$, and the least members at the age of 26-30 years were 2 people (3.5\%).

Age is the length of time lived or existed since birth or existence. Age categories are based on traits and developmental characteristics, namely early adolescence (12-16 years), late adolescence (17-25 years). According to the research results above, it can be seen that more adolescents aged 20-25 years. This shows that this age is the productive age to become a student and has a broader understanding and innovation than the younger age, therefore more people follow Mahatala Unjani [14].

\section{Description of Faculty Characteristics to Respondents}

Description of the characteristics of Mahatala Unjani member respondents by faculty can be seen in Table 3 below:

TABLE III. DESCRIPTION OF THE FACULTIES OF MAHATALA UNJANI MEMBERS

\begin{tabular}{|l|c|c|}
\hline \multicolumn{1}{|c|}{ Characteristic } & \multirow{2}{*}{ Frequency } & \multirow{2}{*}{ Percentage } \\
\cline { 1 - 1 } Social Sciences and Goverment & 4 & 7.0 \\
\hline Technique & 2 & 3.5 \\
\hline Electrical Engineering & 8 & 14.0 \\
\hline Industrial Engineering & 6 & 10.5 \\
\hline Manufacturing Engineering & 29 & 50.9 \\
\hline Mechanical Engineering & 8 & 14.0 \\
\hline Total & 57 & 100.0 \\
\hline
\end{tabular}

The distribution of respondent faculties, namely the majority in the manufacturing engineering faculty with a total of 29 people $(50.9 \%)$, mechanical and electrical engineering with a total of 8 people (14\%), industrial engineering as many as 6 people (10.5\%) and FISIP as many as 4 people (7.0\%).

Based on administrative data on Mahatala Unjani, it was found that the most enthusiasts who became Mahatala members were from the engineering faculty because the engineering faculty was dominated by the male gender and had strong physical and mental abilities to follow Mahatala Unjani.

\section{Description of Respondents Climbing Experience Characteristics}

The description of the characteristics of Mahatla Unjani member respondents based on their climbing experience can be seen in Table 4 below:

TABLE IV. DESCRIPTION OF CLIMBING EXPERIENCE FOR MAHATALA UNJANI MEMBERS

\begin{tabular}{|l|c|c|}
\multicolumn{1}{|c|}{ Characteristic } & \multirow{2}{*}{ Frequency } & \multirow{2}{*}{ Percentage } \\
\hline 1 time & 7 & 12.3 \\
\hline 2-3 times & 9 & 15.8 \\
\hline$>3$ times & 41 & 71.9 \\
\hline Total & 57 & 100.0 \\
\hline
\end{tabular}

Based on the ascent carried out by Mahatala Unjani members, most of them had more than 3 times with a total of 41 people $(71.9 \%)$, then 9 people $(15.8 \%)$ climbed $2-3$ times and 1 climbed as many as 7 people $(12.3 \%)$.

Experience is a learning and potential development enhancement in behavior both from formal and non-formal education that has been experienced or undertaken. Experience includes the many types of jobs or positions a person has occupied and the length of time they have worked in each particular job or position. This result is more people who have climbed $>3$ times and it is by Mahatala's goals [15].

\section{E. Description of the Length of Membership Characteristics of Respondent}

The description of the characteristics of the respondents of Mahatala Unjani members based on the length of membership can be seen in Table 5 below:

TABLE V. DESCRIPTION OF THE LENGTH OF MEMBERSHIP OF MAHATALA UNJANI MEMBERS

\begin{tabular}{|l|c|c|}
\hline \multicolumn{1}{|c|}{ Characteristic } & \multirow{2}{*}{ Frequency } & \multirow{2}{*}{ Percentage } \\
\hline < 1 year of membership & 9 & 15.8 \\
\hline 1-2 years & 21 & 36.8 \\
\hline > 3 years & 27 & 47.4 \\
\hline Total & 57 & 100.0 \\
\hline
\end{tabular}

Based on the length of the organization, most of the Mahatala Unjani members have joined the organization for more than 3 years with 27 people $(47.4 \%), 21$ people $(36.8 \%)$ $1-2$ years, and $<1$ year as many as 9 people $(15.8 \%)$.

The results above are more respondents who have been $>3$ years as Mahatala members, this will be by the theory of Notoatmodjo that the researcher assumes that the longer they become members, the knowledge gained will increase because 
in the process they will experience sharing of knowledge and experience [15].

\section{F. Description of the Characteristic of Having Done First Aid}

The description of the characteristics of the respondent members of Mahatala Unjani based on their experience of doing hypothermic first aid can be seen in Table 6 below:

TABLE VI. THE DESCRIPTION OF THE EXPERIENCE OF DOING HYPOTHERMIC FIRST AID FOR RESPONDENTS

\begin{tabular}{|l|c|c|}
\hline \multicolumn{1}{|c|}{ Characteristic } & Frequency & \multirow{2}{*}{ Percentage } \\
\hline Ever & 41 & 71.9 \\
\hline Never & 16 & 28.1 \\
\hline Total & 57 & 100.0 \\
\hline
\end{tabular}

Distribution of respondents regarding the experience of doing first aid with hypothermia, as many as 41 people $(71.9 \%)$ had done it and 16 people $(28.1 \%)$ had never done it.

This will be following the theory of Notoatmodjo 15 that experience is a way to obtain the truth of knowledge. Researchers assume that those who have done hypothermic first aid will have fairly good knowledge than those who have not [15].

\section{G. Description of Hypothermic First Aid Knowledge Level in Mahatala Unjani Members}

TABLE VII. THE DESCRIPTION OF THE LEVEL OF KNOWLEDGE OF HYPOTHERMIC FIRST AID FOR MEMBERS OF MAHATALA UNJANI

\begin{tabular}{|l|c|c|}
\hline \multicolumn{1}{|c|}{ Knowledge level } & Frequency & Percentage \\
\hline Good & 10 & 17.5 \\
\hline Enough & 26 & 45.6 \\
\hline Less & 21 & 36.8 \\
\hline Total & 57 & 100.0 \\
\hline
\end{tabular}

The results of the research on the level of knowledge of hypothermic first aid for members of Mahatala Unjani in Table 7 show that respondents with good knowledge were 10 people (17.5\%), knowledgeable enough as many as 26 people (45.6\%) and less known as many as 21 people (36.8\%).

The theory of knowledge according to Notoatmodjo [15] states that knowledge is the result of knowing, and this occurs after people sense a certain object. Sensing occurs through the five human senses, namely the senses of sight, hearing, smell, taste, and touch. Most human knowledge is obtained through the eyes and ears. This knowledge is an important part of shaping one's knowledge $[15,16]$.

The results of this study are consistent with the research conducted by Joseph in India. Based on Joseph's research in 2014, the prevalence of first aid knowledge level was $13.8 \%$ had good knowledge, $68.4 \%$ had sufficient knowledge, and $17.8 \%$ had low knowledge [12]. Not all Mahatala Unjani members are well-informed even though the assessment based on age and experience is good, many factors influence members to have a knowledge including, education such as lack of training for Mahatala Unjani members, mass media/information such as lack of sharing of information on members and incidents hypothermia, socio-culture, the environment such as the lack of sharing knowledge about hypothermia with other members, economics such as inadequate facilities even though this is not reasoning but affects knowledge and the environment such as a lack of sharing with other members [15].

\section{H. Description of Hypothermic First Aid Knowledge Levels Based on Age}

The description of the level of knowledge of hypothermic first aid based on age can be seen in Table 8 the following.

TABLE VIII. THE DESCRIPTION OF THE LEVEL OF KNOWLEDGE OF HYPOTHERMIC FIRST AID BASED ON AGE

\begin{tabular}{|l|l|l|l|l|l|l|l|}
\hline \multirow{3}{*}{ Age } & \multicolumn{6}{|c|}{ Knowledge level } & \multirow{2}{*}{ Total } \\
\cline { 2 - 7 } & \multicolumn{2}{|c|}{ Good } & \multicolumn{2}{c|}{ Enough } & \multicolumn{2}{c|}{ Less } & \multirow{1}{*}{} \\
\cline { 2 - 7 } & $\boldsymbol{n}$ & $\boldsymbol{\%}$ & $\boldsymbol{n}$ & $\boldsymbol{\%}$ & $\boldsymbol{n}$ & $\boldsymbol{\%}$ & \\
\hline <20 years & 0 & 0.00 & 2 & 40.00 & 3 & 60.0 & 5 \\
\hline 20-25 years & 9 & 18.00 & 23 & 46.0 & 18 & 36.0 & 50 \\
\hline 26-30 years & 1 & 50.00 & 1 & 50.0 & 0 & 0.0 & 2 \\
\hline Total & 10 & 17.54 & 26 & 45.6 & 21 & 36.8 & 57 \\
\hline
\end{tabular}

The results of the research on knowledge-based on age in table 8 above show that: Out of 5 people aged $<20$ years, 2 (40\%) had sufficient knowledge and $3(60 \%)$ had poor knowledge. Of the 50 people aged $20-25$ years, 9 (18\%) had good knowledge, 23 people (46\%) had enough knowledge and 18 people $(36.0 \%)$ had less knowledge. From 2 people aged 26-30 years, 1 person $(50 \%)$ has good and sufficient knowledge.

According to Widyastuti [14], namely early adolescence (12-16 years), late adolescence (17-25 years). According to the research results above, it can be seen that more adolescents aged 20-25 years. This shows that it is older age who has a broader understanding than a younger age. This age affects a person's perceptive power and mindset. As you get older, your comprehension and mindset will also develop, so that the knowledge you get will be easier and of course better [14].

\section{Description of Hypothermic First Aid Knowledge Levels Based on Climbing Experience}

The description of the level of knowledge of hypothermic first aid based on the duration of the climb can be seen in Table 9 below:

TABLE IX. DESCRIPTION OF THE LEVEL OF KNOWLEDGE OF HYPOTHERMIC FIRST AID BASED ON THE DURATION OF THE CLIMB

\begin{tabular}{|l|c|c|c|c|c|c|c|}
\hline \multirow{2}{*}{$\begin{array}{c}\text { Climbing } \\
\text { experience }\end{array}$} & \multicolumn{6}{|c|}{ Knowledge level } & \multirow{2}{*}{ Total } \\
\cline { 2 - 7 } & \multicolumn{2}{|c|}{ Good } & \multicolumn{2}{c|}{ Enough } & \multicolumn{2}{c|}{ Less } & \\
\cline { 2 - 7 } & $\boldsymbol{n}$ & $\boldsymbol{\%}$ & $\boldsymbol{n}$ & $\boldsymbol{\%}$ & $\boldsymbol{n}$ & $\boldsymbol{\%}$ & \\
\hline 1 time & 0 & 0.00 & 3 & 42.86 & 4 & 57.14 & 7 \\
\hline $2-3$ times & 1 & 11.11 & 3 & 33.33 & 5 & 55.56 & 9 \\
\hline$>3$ times & 9 & 21.95 & 20 & 48.78 & 12 & $29 . .27$ & 41 \\
\hline Total & 10 & 17.54 & 26 & 45.6 & 21 & 36.8 & 57 \\
\hline
\end{tabular}


The results of the research on knowledge-based on climbing in table 9 above show that: Of the 7 people who climbed 1 time, 3 people $(42.86 \%)$ had sufficient knowledge and 4 people $(57.14 \%)$ had poor knowledge. Of the 9 people who climbed 2-3 times, 1 person $(11.11 \%)$ had good knowledge, 3 people $(33.33 \%)$ had enough knowledge, and 5 people $(55.56 \%)$ had poor knowledge. Of the 41 people who climbed $>3$ times, 9 people $(21.95 \%)$ had good knowledge, 20 people $(48.78 \%)$ had enough knowledge and 12 people (29.27\%) had poor knowledge.

Based on the theory of Budiman and Riyanto [16] which states that repeated experiences can lead to the formation of knowledge. Hikers who have climbed many times will have a good experience. Researchers assume that respondents still have sufficient knowledge even though they have climbed more than 3 times because there are still factors that can affect knowledge, including education such as hypothermic training for Mahatala Unjani members who are still lacking so that it can affect that knowledge [16].

\section{J. Description of Hypothermic First Aid Knowledge Levels Based on Length of Membership}

The description of the level of knowledge of hypothermic first aid based on membership length can be seen in Table 10 below:

TABLE X. DESCRIPTION OF THE LEVEL OF HYPOTHERMIC FIRST AID KNOWLEDGE BASED ON THE LENGTH OF MEMBERSHIP

\begin{tabular}{|l|l|c|c|c|c|c|c|}
\hline \multirow{2}{*}{$\begin{array}{c}\text { Length of } \\
\text { membership }\end{array}$} & \multicolumn{6}{|c|}{ Knowledge level } & \multirow{2}{*}{ Total } \\
\cline { 2 - 7 } & \multicolumn{2}{|c|}{ Good } & \multicolumn{2}{c|}{ Enough } & \multicolumn{2}{c|}{ Less } & \\
\cline { 2 - 7 } & $\boldsymbol{n}$ & $\boldsymbol{\%}$ & $\boldsymbol{n}$ & $\mathbf{\%}$ & $\boldsymbol{n}$ & $\boldsymbol{\%}$ & \\
\hline 1 years & 1 & 11.11 & 3 & 33.33 & 5 & 55.56 & 9 \\
\hline 1-2 years & 3 & 14.29 & 10 & 47.62 & 8 & 38.10 & 21 \\
\hline$>$ 3 years & 6 & 22.22 & 13 & 48.15 & 8 & 29.63 & 27 \\
\hline Total & 10 & 17.54 & 26 & 45.6 & 21 & 36.8 & 57 \\
\hline
\end{tabular}

The results of research on knowledge-based on membership length in table 10 above show that: Of the 9 people with membership duration <1 year, 1 person $(11.11 \%)$ has good knowledge, 3 people $(33.33 \%)$ have sufficient knowledge and 5 people $(55.56 \%)$ have less knowledge. good. Of the 21 people with a membership of 1-2 years, 3 people (14.29\%) had good knowledge, 10 people $(47.62 \%)$ had sufficient knowledge and 8 people $(38.10 \%)$ had poor knowledge. Of the 27 people with a membership of $>3$ years, 6 people $(22.22 \%)$ had good knowledge, 13 people $(48.15 \%)$ had sufficient knowledge and 8 people (29.63\%) had poor knowledge.

The theory put forward by Rahayu [17] is that knowledge is related to experience, that is, the more experience a person has, the more information more and more. Experience can be from a long time being a member. The more often people do something sharing knowledge, the more experience they will get so that someone can have knowledge [17].

\section{K. Description of Hypothermic First aid Knowledge Levels} Based on Experience of Performing Hypothermic First Aid

The description of the level of knowledge of hypothermic first aid based on the experience of doing hypothermic first aid can be seen in Table 11 below:

TABLE XI. THE LEVEL OF KNOWLEDGE OF HYPOTHERMIC FIRST AID BASED ON THE EXPERIENCE OF DOING HYPOTHERMIC FIRST AID

\begin{tabular}{|c|c|c|c|c|c|c|c|}
\hline \multirow{3}{*}{$\begin{array}{l}\text { Experience of } \\
\text { performing } \\
\text { first aid }\end{array}$} & \multicolumn{6}{|c|}{ Knowledge level } & \multirow[t]{3}{*}{ Total } \\
\hline & \multicolumn{2}{|c|}{ Good } & \multicolumn{2}{|c|}{ Enough } & \multicolumn{2}{|c|}{ Less } & \\
\hline & $n$ & $\%$ & $n$ & $\%$ & $n$ & $\%$ & \\
\hline Ever & 8 & 19.51 & 19 & 46.34 & 14 & 34.15 & 41 \\
\hline Never & 2 & 12.50 & 7 & 43.75 & 7 & 42.75 & 16 \\
\hline Total & 10 & 17.54 & 26 & 45.6 & 21 & 36.8 & 57 \\
\hline
\end{tabular}

The results of the research on knowledge-based on having done hypothermic first aid in table 11 above show that: Of the 41 people who had done hypothermic first aid, 8 people $(19,511 \%)$ had good knowledge, 19 people $(46.34 \%)$ had sufficient knowledge and 14 people (34.15) \%) lack of knowledge. Of the 16 people who never did hypothermic first aid, $2(12.50 \%)$ had good knowledge, $7(43.75 \%)$ had sufficient and poor knowledge.

Based on the theory from Notoatmodjo [15], it is said that knowledge can be obtained from experience both from personal experience and from other people's experiences and experience is a way to obtain the truth of knowledge. Researchers assume that respondents still have sufficient knowledge because there are still factors that do not support knowledge, one of which is the environment. This factor affects the process of entering knowledge into a person who is in that environment. This happens because of reciprocal interaction or not which will be responded to as knowledge by each person $[15,16]$.

\section{CONCLUSION}

Based on the results and discussion, it can be concluded that the level of knowledge of hypothermic first aid for members of Mahatala Unjani still not good enough, so they have to increase their knowledge about hypothermic first aid.

\section{REFERENCES}

[1] B. Darmowidjojo, Hypothermia, vol. 1. Edition 4. Jakarta: Internal Publishing, 2014, pp. 975-80.

[2] K. Zafren, G.G. Giesbrecht, D.F. Danzl, H. Brugger, E.B. Sagalyn, B Walpoth, and C.K. Grissom, "Wilderness Medical Society practice guidelines for the out-of-hospital evaluation and treatment of accidental hypothermia," Wilderness \& environmental medicine, vol. 25, pp. 425 445, 2014.

[3] I.I. Jeican, "The pathophysiological mechanisms of the onset of death through accidental hypothermia and the presentation of "The little match girl” case," Clujul Medical, vol. 87, pp. 54, 2014.

[4] H.W. Wijaya, Track record of climbing 44 mountains in the archipelago. Yogyakarta. Andi, 2011, p. 25-8. 
[5] J. Biem, N. Koehncke, D. Classen, and J. Dosman, "Out of the cold: management of hypothermia and frostbite," Cmaj, vol. 168, pp. 305-311, 2003 .

[6] J.J. O’Connell, D.A. Petrella, and R.F. Regan, “Accidental hypothermia \& frostbite: Cold-related conditions," Health Care of Homeless Persons Part II, pp. 189-197, 2004.

[7] L. Sari, Gambaran Pengetahuan Mahasiswa Pencinta Alam Universitas Pendidikan Indonesia (Mapala UPI) Tentang Hipotermia Saat Pendakian Gunung. Bandung: Universitas Pendidikan Indonesia, 2018.

[8] A. Mulya, Perancangan Prototype Botol Minum Pemanas Air Portabel Untuk Mengantisipasi Resiko Penyakit Hipotermia Pendaki Gunung Dengan Menggunakan Metode Quality Function Deployment (QFD) Riau: Universitas Negeri Sultan Syarif Kasim Riau, 2020.

[9] M. Musliha, Emergency Nursing. Yogyakarta: Nuha Medika, 2009, p. 40-46.

[10] S. Sugiyono, Educational Research Methods with Quantitative Approaches, Qualitative, and R \& D. Bandung: Alfabeta, 2013, p. 67-68.

[11] T. Susilo, Siap mendaki! Panduan Dasar Kegiatan Pendakian. Jakarta: Green Campus Outdoor, 2012. 65-63
[12] N. Joseph, G. Kumar, Y. Babu, M. Nelliyanil, and U. Bhaskaran, "Knowledge of first Aid and Skills Among of Medical College in Mangalore City of South India," Annals of Med and Sci Health Research, vol. 4, pp. 162-166, 2014.

[13] Y. Naldi, A. Sutisna, and P.P. Nugroho, "Hubungan Pengetahuan Hipotermi dengan Perilaku Penanganan Awal Hipotermi pada Mahasiswa Pencinta Alam di Unswagati dan IAIN Syekh Nurjati Kota Cirebon," Tunas Medika Jurnal Kedokteran \& Kesehatan, vol. 4, pp. 037-043, 2018.

[14] Y. Widyastuti, A. Rahmawati, and Y.E. Purnamaningrum, Kesehatan reproduksi, Yogyakarta: Fitramaya, 2009.

[15] S. Notoatmodjo, Health research methodology. Jakarta: Rineka Cipta, 2012, p. 111-120.

[16] B. Budiman and A. Riyanto, Kapita Selekta Kuesioner Pengetahuan dan Sikap dalam Penelitian Kesehatan. Jakarta: Salemba, 2014, p. 84-89.

[17] S.K. Rahayu, Perpajakan Indonesia: konsep dan aspek formal. Yogyakarta: Graha Ilmu, 2010. 